R. Turmanidze, G. Popkhadze, Tbilisi, K. Inasharidze , Batumi, Georgia

\title{
IMPROVING THE PERFORMANCE CHARACTERISTICS OF HUMAN HIP-JOINT IMPLANTS BY INCREASING THE QUALITY OF PROCESSING AND GEOMETRIC ACCURACY OF THEIR SPHERICAL SURFACES
}

\begin{abstract}
In view of the fact that the endo-prosthesis heads of human hip-joint are operated in extreme conditions, in respect of load, the selection of corresponding material and also increase of precision and quality of machining of spherical surfaces is rather topical task.

In the submitted work are reviewed the problems connected with definition of the influence degree of orientation of the sapphire crystal on its workability during diamond grinding with a butt of the ring and elaboration of the perspective, original scheme of formation of the incomplete spherical surface, particularly, of the sapphire head of endo-prosthesis of the human hip-joint.
\end{abstract}

Keywords: single crystal sapphire, anisotropy, grind ability, endo-prosthesis, precision grinding, forming and spherical surface.

In the last thirty years, one of the current trends in the field of material processing by cutting is the production of implants from different materials for hipjoints with high performance properties, which will ensure their use for more than 30-40 years. This is due to the fact that the heads of the said endoprosthesis, in terms of the nature and magnitude of the load, are operated under extreme conditions. Therefore, in each specific case, the selection of the necessary material with the appropriate physical and mechanical characteristics, as well as improving the accuracy and quality of processing of the most significant part of the endoprosthesis - spherical surfaces, is a very important task, the severity of which has been rapidly increasing in recent years. This is due to the fact that if earlier the need for such operations was mainly caused by the age factor of a person or traumatic fractures, then in the last twenty years the number of patients at a young age has sharply increased, even at 30-40 years old, both men and women, without any injuries or fractures. According to doctors, the main reasons for this disaster are the inactive lifestyle of young people, the composition of modern artificial foods and metabolic disorders, as well as the intensive growth of various fractures as a result of transport and other accidents. All of the above reasons determine the number of endoprostheses used - several tens of millions of pieces per year and statistics show that, unfortunately, this number is increasing annually.

Medical practice proves that the repeated prosthetics of the human hip joint is associated with great problems. In many cases, the implementation of such 
transactions becomes almost impossible. Therefore, the service life of a hip joint endoprosthesis until the end of life for a patient, especially after operations at a young age, is extremely important.

This circumstance explains the fact that in such leading countries of the world as the USA, Germany, England, Japan, France, etc., large-scale research work is being carried out to develop optimal shaping schemes, characteristics of abrasive tools for finishing operations and the technological process as a whole, for the manufacture of spherical endoprosthesis heads from different materials with a minimum form error and with high surface quality indicators.

Today, in world practice, these heads are made from various alloys, composite materials and ceramics, which are mainly isotropic materials. Therefore, the data of the above-mentioned works do not provide the necessary information on the processing of anisotropic materials, in particular, an artificial sapphire crystal.

In addition, the wear resistance of the aforementioned materials in most cases does not meet the requirements for them. And our comparative experiments prove that the most biocompatible with the human body, wear-resistant and durable material for the production of the above-mentioned product is an artificial monocrystal of sapphire.

In this regard, an international project was carried out by the Ukrainian Science and Technology Center, the executors of which were the Georgian Technical University (Tbilisi), the Institute of Super hard Materials of the National Academy of Sciences of Ukraine (Kiev) and the Institute of monocrystal of the National Academy of Sciences of Ukraine (Kharkov).

The project participants solved certain scientific problems, in particular: the Georgian Technical University investigated the effect of sapphire crystal anisotropy on the machinability and quality of the material surface during grinding; promising, theoretical schemes for the shaping of an incomplete spherical surface have been developed in order to improve the geometric accuracy of the spherical part of the endoprosthesis, which is of fundamental importance for increasing the service life of their operation by increasing the contact area between pairs of endoprostheses and, accordingly, reducing the load per unit area their contact surfaces. The Institute for Super hard Materials investigated the relationship between the friction coefficient and the crystallographic features of sapphire and annealing modes; machinability of materials with anisotropy of properties, in particular sapphire, according to traditional technology to assess the effect of anisotropy on the accuracy of shaping a spherical surface; Recommendations have been developed for the process of diamond finishing of the heads of endoprostheses of the hip joint made of artificial sapphire monocrystal. The Kharkov Institute of monocrystals investigated the optimal growth regimes that ensure the maximum purification of the sapphire material, as a result of which a 
sapphire with a crystallographic direction having a minimum anisotropy was obtained.

The aim of the presented work is: to determine the degree of influence of the orientation of the sapphire crystal on its processing by grinding by the NSP method created at the Department of Mechanical Engineering Technology of the Georgian Technical University and the development of a promising, original scheme the shaping of an incomplete spherical surface, in particular, a sapphire head of a human hip joint endoprosthesis. A detailed description of the low-temperature grinding process (LGP) method, the kinematic diagram of the laboratory setup and the experimental technique can be found in previous publications $[1,2,3,4]$.

Studies of the influence of the orientation of the sapphire crystal on the workability of the material were carried out on sapphire samples with the orientation (0001), (1010) and (1012). Sample sizes: 10x10x6 mm and $\Phi$ 10x6 mm.

Experimental studies were carried out on a laboratory setup equipped with a special precision head. We used diamond wheels with grain size 14/10 and 28/20 on ceramic, metal and organic bonds, form 6A2.

The output parameters of the process were: processing productivity, linear minute material removal - $\mathrm{q}, \mu \mathrm{m} / \mathrm{min}$; height of surface roughness irregularities $\mathrm{Rz}, \mu \mathrm{m}$; relative reference profile length at level $03-\mathrm{t}_{\mathrm{P} 03}, \%$; under-relief damaged layer - H, $\mu \mathrm{m}$.

Process factors cutting speed $-\mathrm{V}, \mathrm{m} / \mathrm{s}$; pressure in the cutting zone $\mathrm{P}, \mathrm{kPa}$ and characteristics of the diamond tool: grain size $-\mathrm{d}_{3}, \mu \mathrm{m}$; concentration bundle $\mathrm{K}, \%$.

The experiments were carried out under the following conditions: cutting speed range $-\mathrm{V}=1 \ldots 12 \mathrm{~m} / \mathrm{s}$; pressure in the cutting zone $-\mathrm{P}=100 \ldots 1500 \mathrm{kPa}$. Cooling liquid - filtered running water.

Based on the analysis of the data of our complex, comprehensive experimental studies, we can draw the following conclusion:

The nature of the influence of process factors on the output parameters for the selected orientations of the sapphire crystal $((0001),(1010),(1012))$ is constant.

All other things being equal, the most difficult to machine is the orientation (0001). For all tested diamond wheels, the ratio of linear material removal - $\mathrm{q}$ is within the range

while,

$$
\mathrm{q}_{0001} / \mathrm{q}_{1010}=0,25 \ldots 0,5,
$$

$$
\mathrm{q}_{1012} / \mathrm{q}_{1010}=0,75 \ldots 1 \text {. }
$$

In the studied ranges of cutting modes $\mathrm{V}$ and $\mathrm{P}$, the processing productivity increases at $\mathrm{V}=\ldots 6 \mathrm{~m} / \mathrm{s}$, and at $\mathrm{V}>6 \mathrm{~m} / \mathrm{s}$ - it remains constant, also at $\mathrm{P}=100 \ldots$ $1500 \mathrm{kPa}$ - it grows, at P> $1500 \mathrm{kPa}$ - remains almost constant. 
Of the characteristics of a diamond tool, the grit size and bond of the diamond tool predominantly affect productivity. The effect of concentration is negligible. With an increase in the grain size within $d_{3}=14 / 10 \ldots 28 / 20$, the productivity increases by $1.5 \ldots 2.5$ times.

The maximum value of productivity is achieved by a tool on a ceramic bond SK6 - $130 \ldots 300 \mu \mathrm{m} / \mathrm{min}$, for all selected orientations of the sapphire crystal. This increases the ratio

$\mathrm{q}_{0001} / \mathrm{q}_{1010}=0,4 \ldots 0,5$.

The tool on this bond works in self-sharpening mode.

All other things being equal, processing on the (0001) orientation achieves a higher surface quality than on the other two. The difference is in $1 \ldots 1.5$ grades of roughness.

The surface quality is predominantly influenced by the grit size and the material of the tool bond. With an increase in the grain, in the investigated range, the height of the irregularities Rz grows within $1 \ldots 1.5$ class, and the depth of the disturbed layer $\mathrm{H}-1.5 \ldots 2$ times.

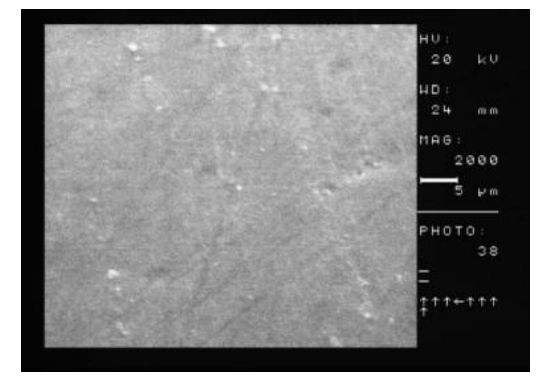

a

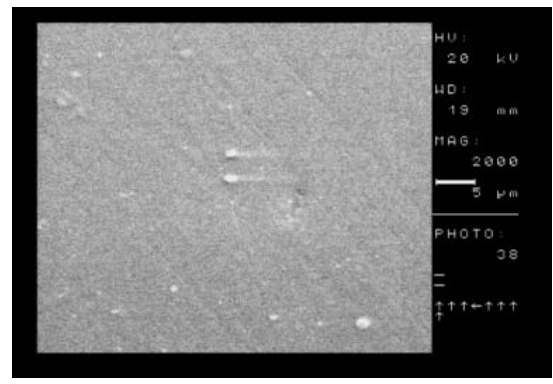

B

Figure 1-Micrographs of surfaces of experimental sapphire samples processed by the NSP method:

a- Orientation 1010, b- 1012. Diamond wheel - ACM 14/10, special organic bond, 50\%.

Cutting conditions: $\mathrm{V}=1 \mathrm{~m} / \mathrm{s}, \mathrm{P}=750 \mathrm{kPa}$

In terms of the quality of the treated surface, the best results are obtained by diamond wheels on organic bonds VS-11 and organic special ones, which have been developed by us and are in the process of patenting. Compared to diamond wheels on metal and ceramic bonds, the Rz parameter is an order of magnitude lower $\sim 0.25 \mu \mathrm{m}$, the $\mathrm{t}_{\mathrm{P} 03}$ parameter is 1.5 higher than $\sim 35 \ldots 45 \%$ and the $\mathrm{H}$ parameter in $3 \ldots 5$ is less than $\sim 2 \ldots 5 \mu \mathrm{m}$.

The study of the morphology of the treated surface proved the possibility of cutting sapphire material by plastic deformation of the removed layer at low 
cutting speeds $\mathrm{V}=1 \ldots 3 \mathrm{~m} / \mathrm{s}$, with the smallest depth of the damaged under-relief layer (Fig. 1).

This result is worthy of special attention, since the processing of glassy materials, in particular, a sapphire crystal, by plastic deformation of the removed layer is a guarantee of obtaining a treated surface with practically no hereditary defects - without a disturbed under-relief layer. The value of $\mathrm{H}$ turned out to be the smallest in these sapphire samples.

The development of a new, or improvement of the existing technological process of mechanical processing of a sapphire head poses an urgent task of creating new, highly efficient shaping schemes. Optimization criteria for technological operations, such as productivity, surface quality indicators and processing accuracy, determine the place of new shaping schemes in the technological process, taking into account their advantages.

The methods of abrasive processing of an incomplete spherical surface of general-purpose products used today, as separate operations of the technological process of machining an incomplete sphere, can be divided into two groups: grinding with abrasive diamond wheels, finishing with a free abrasive.

Our method belongs to the first group, however, as a method for diamond abrasive processing of flat surfaces, in contrast to existing methods, it combines the positive aspects of the methods of the above two groups, namely: with high processing accuracy and surface quality.

To develop a theoretical scheme for diamond processing of sapphire spheres, taking into account the kinematic and other positive features of the NSP, the known schemes for the formation of an incomplete spherical surface were considered and analyzed.

The closest in kinematics to the NSP method is the method of grinding an incomplete sphere with the end of a grinding wheel with double rotation of the part with angular velocities $\omega_{2}$ and $\omega_{3}$ (Fig. 2), which is taken as the basis for the development of an original version of the theoretical scheme of diamond processing of sapphire spheres, taking into account the kinematic and other positive features of the NSP method.

We have developed several versions [5,6] of theoretical schemes for the formation of an incomplete spherical surface. One version of the original kinematic scheme for shaping an incomplete spherical surface of a sapphire head (Fig. 3) by an end grinding wheel is shown in (Fig. 4). The cutting tool is a special, combined face grinding wheel with two concentric diamond-bearing layers, with cutting surfaces in the form of internal, at point A, and external, at point B, cut off cones.

The grinding wheel rotates with an angular velocity $\omega_{1}$. The workpiece being machined - the ball - performs a double rotary motion with angular velocities $\omega_{2}$ around its own axis 4 and $\omega_{3}$ around axis 3 , which is the axis of the part's spindle. The direction of the angular velocities $\omega_{1}, \omega_{2}$ and $\omega_{3}$ is the same. The workpiece 2 
to be machined is pressed against the cutting surface of the grinding wheel at two points A and B by a spring-loaded force P. In this case, the cutting surfaces of the grinding wheel in the axial section form an angle $\beta$.

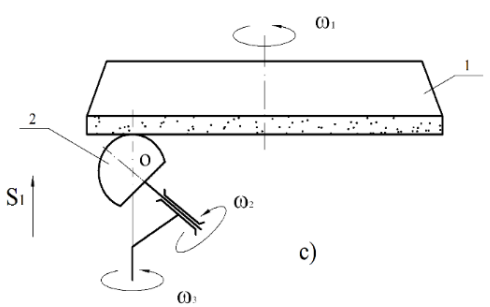

Figure 2 - Scheme of forming an incomplete spherical surface with an end diamond wheel with double rotation of the part:

1 - diamond grinding wheel;

2 - work piece - incomplete sphere
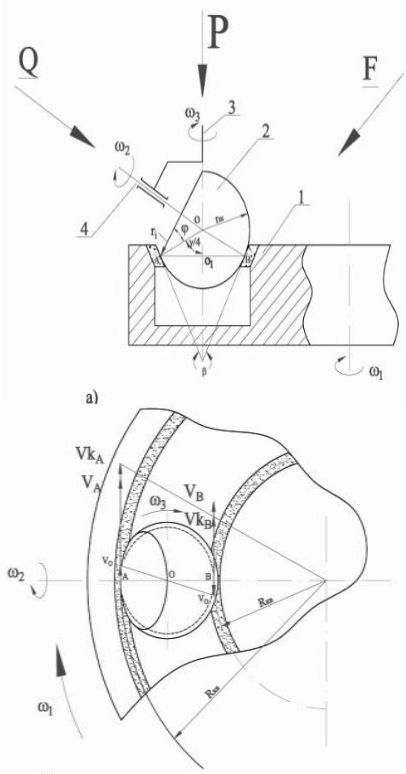

b)

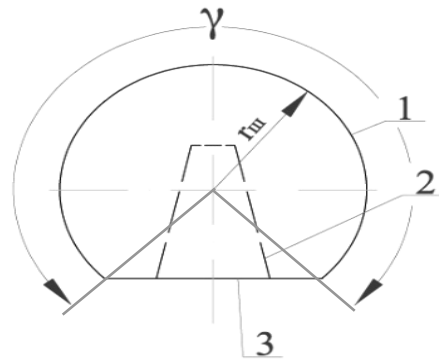

Figure 3 - Sapphire Ball Head:

$\mathrm{r}_{\amalg}$ is the radius of the sphere;

$\gamma$ is the angle of the spherical surface segment
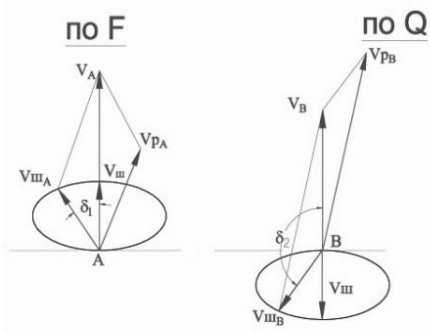

c)

d)

Figure 4 - Kinematic diagram of shaping incomplete spherical end face grinding based on the NPS method: 1 - face grinding wheel; 2 - work piece - incomplete sphere; 3 - axis of rotation of the part spindle; 4 - the axis of rotation of the part 
Distinctive features of the theoretical scheme from the NSP such as the shape of the working surface of the tool, additional movement of the workpiece - rotation of the ball around its own axis at a speed $\omega_{2}$, the form of contact of the workpiece surface with the cutting surface of the grinding wheel.

To create equal processing conditions at two points A and B, it is necessary to observe the equality of both the speeds and the cutting forces.

Cutting speed. Equality of processing conditions in terms of cutting speed means equality of the maximum values of cutting speeds and the identity of their laws of change in the cycle in two cutting zones.

Cutting speeds when grinding an incomplete sphere according to the proposed scheme at points A and B are given in Fig. 4 c, c, and d.

Resulting cutting speed $\mathrm{V}_{\mathrm{PA}^{-}}$at point $\mathrm{A}$

$$
\begin{gathered}
\overrightarrow{\mathrm{v}}_{\mathrm{PA}}=\overrightarrow{\mathrm{v}}_{\mathrm{B}}-\overrightarrow{\mathrm{v}}_{\mathrm{WB}} \\
\mathrm{v}_{\mathrm{P}_{\mathrm{A}}}=\sqrt{\mathrm{v}_{\mathrm{A}}^{2}+\mathrm{v}_{{ }_{\mathrm{A}}}^{2}-2 \mathrm{v}_{\mathrm{A}} \cdot \mathrm{v}_{\mathrm{WA}_{\mathrm{A}}} \cdot \cos \delta_{1}} \\
\mathrm{v}_{\mathrm{A}}=\mathrm{v}_{\mathrm{KA}}-\mathrm{v}_{\mathrm{O}}=\mathrm{R}_{\mathrm{KA}} \cdot \omega_{1}-\mathrm{r}_{\mathrm{W}} \sin \frac{\gamma}{4} \cdot \omega_{3} \\
\text { and } \quad \mathrm{v}_{\mathrm{WA}}=\mathrm{r}_{\mathrm{iA}} \cdot \omega_{2} .
\end{gathered}
$$

Similar to point $A$, at point $B$ the resulting cutting speed is

$$
\begin{gathered}
\overrightarrow{\mathrm{v}}_{\mathrm{PB}}=\overrightarrow{\mathrm{v}}_{\mathrm{B}}-\overrightarrow{\mathrm{v}}_{\mathrm{WB}}, \\
\mathrm{v}_{\mathrm{P}_{\mathrm{B}}}=\sqrt{\mathrm{v}_{\mathrm{B}}^{2}+\mathrm{v}^{2}{ }_{{ }_{\mathrm{B}} \mathrm{B}}-2 \mathrm{v}_{\mathrm{B}} \cdot \mathrm{v}_{\mathrm{W}_{\mathrm{B}}} \cdot \cos \delta_{2}} \\
\mathrm{v}_{\mathrm{B}}=\mathrm{v}_{\mathrm{KB}}-\mathrm{v}_{\mathrm{o}}=\left(\mathrm{R}_{\mathrm{KA}}-2 \mathrm{r}_{\mathrm{II}} \cdot \sin \frac{\gamma}{4}\right) \cdot \omega_{1}+\mathrm{r}_{\mathrm{II}} \cdot \sin \frac{\gamma}{4} \cdot \omega_{3} \\
\text { and } \quad \mathrm{v}_{\mathrm{UB}}=\mathrm{r}_{\mathrm{i} B} \cdot \omega_{2} .
\end{gathered}
$$

Linear speed of the part from rotary motion with angular speed $\omega_{2}$

$$
\omega_{2} \cdot r_{u} \sqrt{\sin ^{2} \frac{\gamma}{4} \cdot \cos ^{2} \alpha+\frac{1}{4} \cdot \sin ^{2} \frac{\gamma}{2}(1+\sin \alpha)^{2}}
$$


Where is $\varphi$ the angle of inclination of the axis 4 relative to the generatrix of the working surface of the circle in the axial section, $\alpha$ is the angle of rotation of the axis 4 relative to the axis 3 with an angular velocity $\omega_{3}$.

The current radius of the point of the surface of the part, when you rotate axis 4 around axis 3 by $180^{\circ}$, changes within $\mathrm{O} \leq \mathrm{r}_{\mathrm{i}} \leq \mathrm{r}_{\mathrm{m}}$. Thus, for a complete description of a spherical surface during one cycle, one revolution of the part around axis 4 is sufficient, when axis 4 is rotated about axis 3 by half a revolution, i.e. by $180^{\circ}$. Consequently, under these conditions, the processed spherical surface of the part is described twice during one cycle. Once in each treatment area.

Based on the foregoing, between the angular velocities $\omega_{2}$ and $\omega_{3}$ we have the dependence

$$
\omega_{2}=2 \omega_{3} .
$$

$\mathrm{v}_{\mathrm{P}_{\mathrm{A}}}$ reaches a maximum at $\alpha=\pi 3 / 2$, and therefore, $\delta_{1}=\frac{\pi}{2}$.

$$
\mathrm{v}_{\mathrm{P}_{\mathrm{Amax}}}=\mathrm{v}_{\mathrm{A}}=\mathrm{R}_{\mathrm{KA}} \cdot \omega_{1}-\mathrm{r}_{\mathrm{w}} \cdot \sin \frac{\gamma}{4} \omega_{3}
$$

$\mathrm{v}_{\mathrm{P}_{\mathrm{B}}}$ reaches a maximum at $\alpha=\pi / 2$, and therefore, $\delta_{2}=\pi$.

$$
\mathrm{v}_{\mathrm{P}_{\mathrm{Bmax}}}=\mathrm{R}_{\mathrm{KA}} \cdot \omega_{1}-2 r_{\mathrm{II}} \sin \frac{\gamma}{4} \omega_{1}+r_{u} \cdot \sin \frac{\gamma}{4} \cdot \omega_{3}+r_{\mathrm{II}} \sin \frac{\gamma}{2} \omega_{2}
$$

On condition $\mathrm{V}_{\mathrm{P}_{\mathrm{Amax}}}=\mathrm{V}_{\mathrm{P}_{\mathrm{Bmax}}}$, by expressions (10), (11) and (12) the ratio of angular velocities and $\omega_{3}$ и $\omega_{1}$

$$
\frac{\omega_{3}}{\omega_{1}}=\frac{1}{1+2 \cos \frac{\gamma}{4}} .
$$

Thus, according to the proposed scheme for shaping an incomplete spherical surface, in order to achieve equality of processing conditions in terms of cutting speed, it is necessary to observe the ratios of angular speeds $\omega_{1}, \omega_{2}$ and $\omega_{3}$, according to expressions (10) and (13).

Clamping force. The equality of conditions at two points in terms of the clamping force is achieved by the location of the workpiece in relation to the grinding wheel. The spring-loaded force $\mathrm{P}$ passes through the center $\mathrm{O}$ of the sphere and coincides with the bisector of angle $\beta$ and thus passes at equal distances from two A and B processing zones. In each zone, equal efforts on P / 2 are created, which in turn are composed of two components, normal PN and tangential $\mathrm{P} \tau$ (not shown in the figure). Wherein: 


$$
\mathrm{P}_{\mathrm{N}}=\frac{\mathrm{P}}{2} \cdot \cos \frac{\gamma}{4}, \quad \mathrm{P}_{\tau}=\frac{\mathrm{P}}{2} \cdot \sin \frac{\gamma}{4} .
$$

The kinematic similarity of the new shaping scheme with the LPS method, taking into account the preservation of the physics of the cutting process with the LPS, which determined its name "Low temperature" (low compared to conventional grinding, the cutting speed is $-1.6 \mathrm{~m} / \mathrm{s}$ and, as a consequence, the low temperature in contact is $-100^{\circ} \mathrm{C}$ ), also "Precision" (high accuracy of the shape of the working surface of the tool is achieved during straightening and is maintained in operation by the kinematics of the process, which ensures high processing accuracy - plane-parallelism on a $10 \times 10 \mathrm{~mm}<1 \mu \mathrm{m}$ plate), allows the proposed shaping scheme. The name, as coming from the first, is called Lowtemperature precision grinding of an incomplete sphere, in abbreviated form NPSHNS, which is in the process of patenting.

It is assumed that the NPSHNS method, in comparison with the traditional methods of diamond grinding, which are used today in the technological process of mechanical processing of a sapphire head, all other things being equal, will allow: to significantly (at least twice) increase the processing productivity without deteriorating performance surface quality and shape accuracy; to significantly improve the quality of the processed surface and the accuracy of the shape of the product, without increasing the productivity of processing, thereby also significantly reducing the operating allowance, as a result, the time and cost of processing in finishing operations (transitions).

Thus, in our opinion, the NPSHNS method can be quite competitive in preliminary operations, up to finishing, in the technological process of machining a sapphire head.

The long-term program provides for the organization of a European project with the creation of the necessary equipment, tools, technological equipment and the entire technological process for manufacturing high-precision spherical surfaces from various brittle materials of increased strength, including sapphire.

\section{Conclusion}

As a result of the study of the effect of the crystallographic orientation of a sapphire monocrystal on the rate of removal of the processed material, as well as the state of the subsurface layer during surface finishing by the method of lowtemperature flat grinding, it was found that: 
1. The processing capacity of a sapphire monocrystal significantly depends on the crystallographic orientation. The relative values of material removal for samples with different crystallographic orientations (1010) are in the range $\mathrm{q}_{0001} / \mathrm{q}_{1010}=0.25 \ldots 0.5$, and $\mathrm{q}_{1012} / \mathrm{q}_{1010}=0.75 \ldots 1$. Under other equal conditions of the LPS process, the highest quality of the polished surface is achieved for the crystalographic orientation (1010). The difference with the other two orientations of the crystallographic plane is in the range of $1 \ldots 1.5$ roughness class.

2. The study of the morphology of the processed surface proved the possibility of cutting sapphire material by plastic deformation of the removed layer without cracking at a low cutting speed. Under such machining conditions, the smallest depth of the damaged subsurface layer was found.

3. New kinematic schemes for the processing of incomplete spherical surfaces have been proposed, which provide a higher geometric accuracy of parts, in particular, the spherical heads of the human hip joint endoprosthesis.

\section{Acknowledgment}

This work was supported by Shota Rustaveli National Science Foundation (SRNSF) [PHDF-19-2224, Improving the efficiency of mechatronic systems in order to ensure the reform of "Industry-4.0"]

References: 1. Batiashvili B.I., Butskhrikidze D.S., Mamulashvili G.L., Mgaloblishvili O. B., Turmanidze R.S., Kromp K., Mills B., Steinkellner W., Schafler E., Rösel F. G., Peterlik H. Evaluation of surface preparation techniques, SFG: Swing Frame Grinding and LPG: Low Temperature Precision Grinding, by comparison of results on alumni and siliconcarbide model materials. FRACTOGRAPHY OF ADVANCED CERAMICS. International Conference Stará Lesná, High Tatras, May 2001. 2. Batiashvili B.I., Butskhrikidze D.S., Mamulashvili G.A, Turmanidze R.S., Kromp K., Mills B., Mgaloblishvili $O$. Technological Possibilities of Low Temperature Precision Grinding Process when Machining Hard and Brittle Materials. FRACTOGRAPHY OF ADVANCED CERAMICS, International Conference, Stará Lesná, High Tatras, May 2001. 3. Turmanidze R.S, Burtskhrikidze D.S, Kromp K., Mills B., "Low temperature precision grinding of hard and brittle materials". Problems of mechanics and physiko-chemistry of the process of abrasive machining, Kiev 2002, 490-499 pp. 4. Turmanidze R.S., Butskhrikidze D.S., Mamulashvili G.L., Kromp K., Mills B., Morgan M., Mgaloblishvili $O$. Low-temperature precision grinding of hard and brittle materials and Outlook of its development and application. Proceedings of 19th NCMR Conference. Glasgow, September 2003. 5. R. Turmanidze, D. Butskhrikidze, E. Kutelia, M. Beridze, Influence of the Sapphire Crystal Anisotropy of Medical Purpose on Workability of the Endoprosthesis Material at a Low Temperature Precision Grinding. "MicroCAD 2008” International Scintific Conference. 20-21 March, 2008. Section 
N: Production Engine $\neg$ ering and Manufactu $\neg$ ring Systems. University of Mishkolc, Hungary. ISBN 978-963-661-812-4 Ö ISBN 978-963-661-823-0. 6. R. Turmanidze, G. Popkhadze, Selection criteria of optimal characteristic material and technologies for precision processing of basic working surface of human hip-joint implant. 9TH INTERNATIONAL CONGRESS ON PRECISION MACHINING. ATHENS, GREECE-2017, ISSN 0377-6883.Kundrak J., Varga G., Deszpoth I., Molnar V. Some aspects of the hard machining of bore holes // Applied Mechanics and Materials, 309, pp. 126-132 (2013).

Рауль Турманідзе, Георгі Попхадзе, Тбілісі, Кетеван Інашарідзе, Батумі, Грузія

\title{
ПОЛІПШЕННЯ ЕКСПЛУАТАЦЙНИХ ХАРАКТЕРИСТИК ІМПЛАНТІВ КУЛЬШОВИХ СУГЛОБІВ ЛЮДИНИ ШЛЯХОМ ПІДВИЩЕННЯ ЯКОСТІ ОБРОБКИ І ГЕОМЕТРИЧНОЇ ТОЧНОСТІ ЇХ СФЕРИЧНИХ ПОВЕРХОНЬ
}

\begin{abstract}
Анотація. $У$ зв'язку з тим, що головки ендопротезів тазостегнового суглоба людини експлуатуються в екстремальних умовах по навантаженню, вибір відповідного матеріалу, а також підвищення точності і якості обробки сферичних поверхонь $є$ досить актуальним завданням. У поданій роботі розглянуто питання, пов'язані з визначенням ступеня впливу орієнтації кристала сапфіра на його оброблюваність при алмазному шліфуванні торием кола $i$ розробкою перспективної, оригінальної схеми формування неповної сферичної поверхні, зокрема, сапфіровою головки ендопротеза кульшового суглоба людини. В результаті дослідження впливу кристалографічної орієнтачії монокристала сапфіра на інтенсивність знімання оброблюваного матеріалу, а також стану подповерхностного шару при доведенні поверхонь методом низькотемпературного плоского шліфування (НПШ) встановлено, шүо обрабативаемость монокристалла сапфіра значно залежить від крісталографічної орієнтачії. Відносні величини знімання матеріалу при зразках з різними кристалографічними орієнтачіями (1010) знаходяться в межах $q_{00 о 1} / q_{1010}=0.25 \ldots$ 0.5, i $q_{1012} / q_{1010}=0.75 \ldots$ 1. При інших рівних умовах процесу НПШ вища якість шліфованої поверхні досягається для кристалографічної орієнтаџї (1010). Різничя з двома іншими орієнтаціями кристаллографической площині знаходиться в межах 1 ...1.5 класу шорсткості. Вивченням морфологї обробленої поверхні доведена можливість різання матеріалу сапфіра пластичним деформуванням шару, що знімається без утворення тріщин при низькій швидкості різання. При таких умовах механічної обробки була виявлена найменша глибина пошкодженого подповерхностного шару. Запропоновано нові кінематичні схеми обробки неповних сферичних поверхонь забезпечують більш високу геометричну точність деталей з різних матеріалів, зокрема сферичних головок ендопротеза кульшового суглоба людини.
\end{abstract}

Ключові слова: монокристалічний сапфір; анізотропія; подрібнення; ендопротезування; точне иліфування; формування; сферична поверхня. 